\title{
Critical success factors in project management
}

\author{
Maryam Orouji $\mathbf{a}^{\mathrm{a}^{*}}$
}

${ }^{a}$ Department of Industrial Engineering, Iran University of Science and Technology

\begin{tabular}{|c|c|}
\hline CH R O N I C L E & A B S T RACT \\
\hline $\begin{array}{l}\text { Article history: } \\
\text { Received: October 1, } 2016 \\
\text { Received in revised format: No- } \\
\text { vember } 16,2016 \\
\text { Accepted: January 7, } 2017 \\
\text { Available online: } \\
\text { January 7, } 2017 \\
\text { Keywords: }\end{array}$ & $\begin{array}{l}\text { In this survey, we perform a survey on different studies associated with critical success factors } \\
\text { in project management. The study covers all related studies from } 1987 \text { to } 2017 \text { based on the } \\
\text { articles published on different value added journals. The survey shows that tremendous efforts } \\
\text { have been dedicated on important factors, which influence on the success or failure of enterprise } \\
\text { resource planning. The other part of the survey is dedicated for the implementation of Six Sigma } \\
\text { projects. Our survey shows that successful implementation of Six Sigma could contribute to the } \\
\text { success of projects. }\end{array}$ \\
\hline
\end{tabular}

Enterprise resource planning

Six Sigma

CSFs

Project management

\section{Introduction}

During the past few years, there have been different studies on detecting critical success factors (CSFs) of project management (Sumner, 1999; Chua et al., 1999; Lin Moe \& Pathranarakul, 2006; Yalegama et al., 2016). Pinto and Slevin (1987) explained a process implemented to detect CSFs that are predictive of successful project management. Pinto and Slevin (1989) in an assignment detected CFSs for the success of research and development projects. Belassi and Tukel (1996) tried to group the success factors and explained the interaction between them, in addition to the identification of individual factors. They reported several critical factors, such as factors associated with project managers' performance, team members and environmental factors. This paper attempts to perform a survey on efforts dedicated on CFSs on success or failure of project management. The study first review important works on Enterprise Resource Planning in section 2. Section 3 presents a survey on works dedicated on Six Sigma projects. Knowledge based projects are discussed in section 4 and finally conclusion of the survey is given in section 5 to summarize the contribution of the paper.

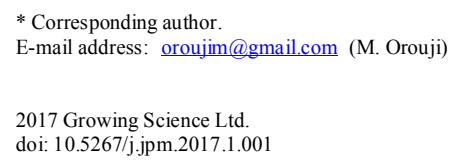




\section{Enterprise Resource Planning}

Enterprise resource planning (ERP) is one of the most important integrated management systems for core business processes. ERP systems are highly complex information systems and the implementation of such systems is a tedious and high cost proposition, which places tremendous demands on corporate time and resources. According to Ahmad and Cuenca (2013) ERP projects are complex and expensive, and, very often, it costs more than what we expect. A good implementation of ERP system has some advantages for big organizations but many ERP systems may fail due to different reasons. ERP system integrates different components of an enterprise. Fig. 1 shows different departments which are involved in an ERP implementation.

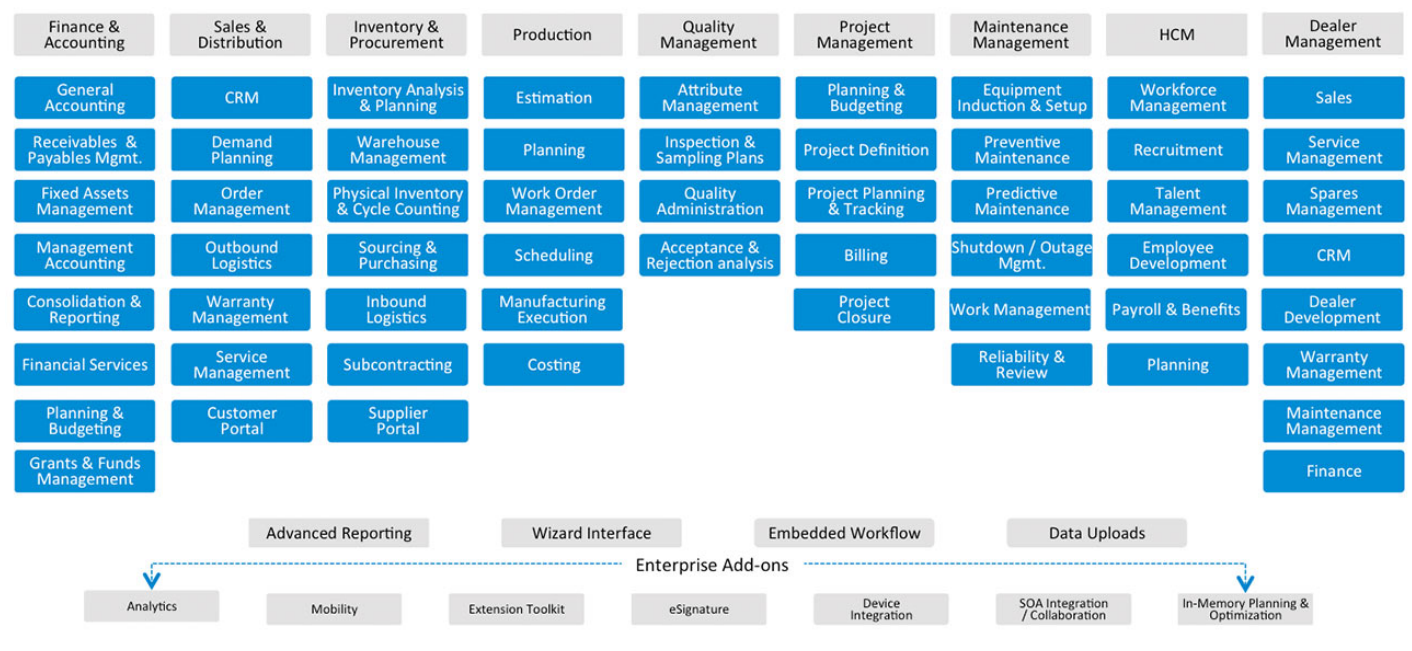

Fig. 1. Enterprise Resource Planning integration

Ahmadi et al. (2015a) proposed a technique to manage various interrelated activities to get ready for implementing an ERP system. The method helps an organization make an assessment on its ERP implementation readiness by evaluating the degree to which it could reach the interrelated readiness relevant activities based on fuzzy cognitive maps. Ahmadi et al. (2015b) performed an empirical investigation to find out how to measure the readiness of a firm for ERP implementation. They estimated readiness based on fuzzy cognitive maps to include all the complex causal relationships among various factors. Ahmadi et al. (2015c) in another assignment implemented fuzzy analytical hierarchy process to determine the key success for ERP implementation.

Holland and Light (1999) provided a comprehensive survey on detecting critical success factors for ERP implementation. Fui-Hoon Nah et al. (2001) detected 11 factors associated with the success ERP implementation including "ERP teamwork and composition; change management program and culture; top management support; business plan and vision; business process reengineering with minimum customization; project management; monitoring and evaluation of performance; effective communication; software development, testing and troubleshooting; project champion; appropriate business and IT legacy systems." Fortune and White (2006) reported the findings of a major review of the sets of factors that are available and outlines the main reservations expressed about the approach. Clarke (1999) presented a method to increase the chance of the success of ERP implementation. Banuelas Coronado and Antony (2002) provided some CSFs for the successful implementation of six sigma projects in organizations. Antoniadis et al. (2015) performed an investigation on ERP systems adoption and implementation by small and Medium Enterprises (SMEs) in the region of Western Macedonia by focusing on the CFSs influencing on adoption of ERPs by SMEs. The factors determined were associated with the surveyed economic and organizational characteristics of the SMEs. The results indicated that although 
SMEs could recognize the advantages gained by the application of these systems, still the business intelligence abilities of ERP systems were underutilized. Kilic et al. (2015) applied Analytic Network Process (ANP) and Preference Ranking Organization Method for Enrichment Evaluations (PROMETHEE) to address the ERP selection problem. They applied ANP to detect the weights of all criteria, and then, applied them in the PROMETHEE method for optimal ranking of the alternative system choices. They also examined their proposed method in SMEs in İstanbul, Turkey.

Umble et al. (2003) identified CFSs, software selection steps, and implementation procedures essential to a successful ERP implementation. Westerveld (2003) proposed a project excellence model adapted from the EFQM-model (Hendricks \& Singhal, 1996) to determine the success criteria and critical success factors for projects. Pinto and Prescott (1988) studied the changes in the importance of project CSFs across four stages in the project life cycle. They reported that the relative importance of several of the critical factors could change substantially based on life cycle stages. Cooke-Davies (2002) performed an empirical survey from more than 70 large multi-national or national firms to determine important factors for the success of project.

Chau et al. (1999) tried to determine the critical success factors based on the project objectives including budget, schedule, and quality. Somers and Nelson (2001) explained the effect of CSFs across the stages of ERP implementations. They provided some advice to decide how best to utilize their limited resources to choose those CSFs that are most likely to have an effect on the implementation of the ERP system. Hong and Kim (2002) reported that ERP implementation success substantially depends on the organizational fit of ERP and certain implementation contingencies. Akkermans and van Helden (2002) explained how one list of CSFs (Somers \& Nelson, 2001) could be implemented to analyze and describe project performance in one ERP implementation in the aviation industry and reported that poor project performance could lead to a serious project crisis.

Based on Armstrong et al. (2015) state, the human brain continually generates electrical potentials representing neural communication, which could be measured at the scalp, and constitute the electroencephalogram (EEG). They applied various pattern classifiers to ERPs representing the response of individuals to a stream of text designed to be familiar to different individuals and reported some robustly identifiable features of the ERP, which capable of labeling of ERPs. Bueno and Salmeron (2008) focused on decisive factors influencing on the ERP users' acceptance and implementation. They used Technology Acceptance Model (TAM) for testing the effect of the CSFs on ERP implementation. The CSFs implemented were: "(1) top management support, (2) communication, (3) cooperation, (4) training and (5) technological complexity".

\section{Six Sigma projects}

Six sigma project looks for improving the quality of the output of a process by detecting and eliminating the causes of defects and optimizing variability in manufacturing and business processes. Six sigma applies a set of quality management techniques, primarily empirical, statistical methods, and builds a special infrastructure of people within the organization. Each Six Sigma project follows a defined sequence of steps and has specific value targets, for instance: reduce process cycle time, reduce pollution, reduce costs, increase customer satisfaction, and increase profits. The maturity of a manufacturing process is normally defined by a sigma rating indicating its yield or the percentage of defect-free products it generates. A six sigma process yields 3.4 defective features per million opportunities. Fig. 2 shows the structure of the Six Sigma implementation. As we can observe from the results of Fig. 2, a Six Sigma project consists of five parts; namely define, measure, analyze, improve and control. Marzagão and Carvalho (2016) determined the relationship between CSFs for Six Sigma programs and its projects performance, according to Six Sigma projects. They explored the relationships through Partial Least Squares method, based on a sample of 149 respondents in Brazil and Argentina. They reported that not all the claimed critical success factors were relevant for program or project performance, what could 
direct the effort of companies into working harder in the relevant ones. The study provided a noteworthy contribution to Six Sigma literature giving a structural model, which indicates the effect of Six Sigma Method, Project Management and the Project Manager competencies on project performance.

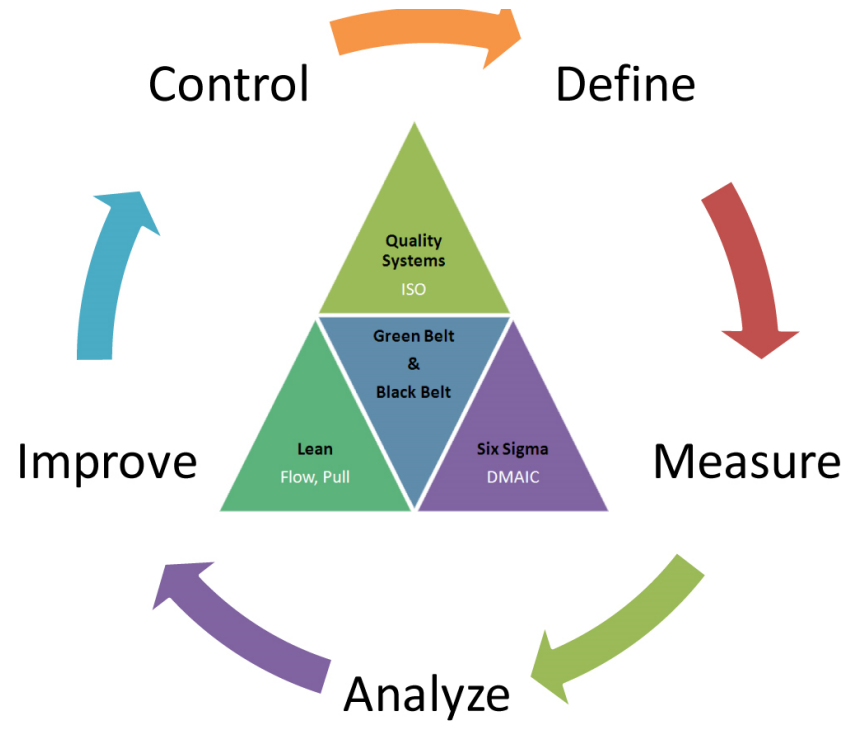

Fig. 2. The structure of Six Sigma implementation

Parast (2011) developed a theoretical base for the effect of Six Sigma projects on innovation and firm performance. In this survey, Six Sigma projects includes technological innovation of the firms. Since Six Sigma programs are concentrated on variance reduction and efficiency, these initiatives are not very efficient in dynamic environments, where the rate of technological change may change significantly. With the emphasis on variance-reduction, Six Sigma programs may be implemented for enhancing incremental innovation. Moreover, since Six Sigma projects concentrate on existing customers, they may impede innovation for new customers. Therefore, implementing Six Sigma projects in fast pace environments with high level of innovation and change may be a tedious task, and might not yield in the expected outcome. Antony et al. (2007) discussed the challenges, difficulties, common myths, and implementation problems in the application of six sigma in service industry settings. The study also discussed the advantages of six sigma in service organizations, tools and methods of six sigma for service performance improvement.

\section{Knowledge based projects}

One of the important issues for knowledge management in a project environment is associated with the weak project success analysis and the insufficient documentation on the results of the previous projects. Todorović et al. (2015) presented an empirical research to define the contribution of project success analysis framework to knowledge management in project environment in Serbia during 2013. They reported that project success analysis, presented through the definition of critical success factors, key performance indicators and performance-measuring process maintained positive effect on knowledge acquisition and transfer in project environment.

Project management information systems (PMIS) usually implemented by firms as software packages are aimed to provide managers with the decision-making support required in planning, organizing, and controlling projects. Raymond and Bergeron (2008) empirically investigated the quality of the PMIS presently implemented in different firms and examined the impact of PMIS on project managers and project performance, based on a PMIS success model. This model consists of five parts: the quality of the PMIS, the quality of the PMIS information output, the use of the PMIS, the individual impacts of the PMIS and the impacts of the PMIS on project success. These systems were found to have direct 
effects on project success, as they contribute for improving budget control and reaching project deadlines as well as fulfilling technical specifications.

\section{Conclusion}

In this paper, we have discussed different efforts on detecting critical success factors on project management. The survey has disclosed that tremendous efforts had been devoted on detecting important factors on enterprise resource planning. This is important when we realize that most ERP projects fail during the implementation or even during the early stage. Therefore, we need to put more efforts on learning success and failure factors before implementing such project. The other part of the survey was dedicated for the implementation of Six Sigma projects. Our survey has shown that successful implementation of Six Sigma could contribute to the success of projects.

\section{Acknowledgement}

The author would like to thank the anonymous reviewer for constructive comments on earlier version of this paper.

\section{References}

Achanga, P., Shehab, E., Roy, R., \& Nelder, G. (2006). Critical success factors for lean implementation within SMEs. Journal of Manufacturing Technology Management, 17(4), 460-471.

Ahmad, M. M., \& Cuenca, R. P. (2013). Critical success factors for ERP implementation in SMEs. Robotics and Computer-Integrated Manufacturing, 29(3), 104-111.

Ahmadi, S., Papageorgiou, E., Yeh, C. H., \& Martin, R. (2015a). Managing readiness-relevant activities for the organizational dimension of ERP implementation. Computers in Industry, 68, 89-104.

Ahmadi, S., Yeh, C. H., Martin, R., \& Papageorgiou, E. (2015b). Optimizing ERP readiness improvements under budgetary constraints. International Journal of Production Economics, 161, 105-115.

Ahmadi, S., Yeh, C. H., Papageorgiou, E. I., \& Martin, R. (2015c). An FCM-FAHP approach for managing readiness-relevant activities for ERP implementation. Computers \& Industrial Engineering, $88,501-517$.

Akkermans, H., \& van Helden, K. (2002). Vicious and virtuous cycles in ERP implementation: a case study of interrelations between critical success factors. European Journal of Information Systems, 11(1), 35-46.

Antoniadis, I., Tsiakiris, T., \& Tsopogloy, S. (2015). Business intelligence during times of crisis: Adoption and usage of ERP systems by SMEs. Procedia-Social and Behavioral Sciences, 175, 299-307.

Antony, J., Jiju Antony, F., Kumar, M., \& Rae Cho, B. (2007). Six sigma in service organisations: Benefits, challenges and difficulties, common myths, empirical observations and success factors. International journal of quality \& reliability management, 24(3), 294-311.

Armstrong, B. C., Ruiz-Blondet, M. V., Khalifian, N., Kurtz, K. J., Jin, Z., \& Laszlo, S. (2015). Brainprint: Assessing the uniqueness, collectability, and permanence of a novel method for ERP biometrics. Neurocomputing, 166(20), 59-67.

Bueno, S., \& Salmeron, J. L. (2008). TAM-based success modeling in ERP. Interacting with Computers, 20(6), 515-523.

Banuelas Coronado, R., \& Antony, J. (2002). Critical success factors for the successful implementation of six sigma projects in organisations. The TQM magazine, 14(2), 92-99.

Belassi, W., \& Tukel, O. I. (1996). A new framework for determining critical success/failure factors in projects. International journal of project management, 14(3), 141-151.

Chua, D. K. H., Kog, Y. C., \& Loh, P. K. (1999). Critical success factors for different project objectives. Journal of construction engineering and management, 125(3), 142-150.

Clarke, A. (1999). A practical use of key success factors to improve the effectiveness of project management. International Journal of Project Management, 17(3), 139-145. 
Fortune, J., \& White, D. (2006). Framing of project critical success factors by a systems model. International Journal of Project Management, 24(1), 53-65.

Fui-Hoon Nah, F., Lee-Shang Lau, J., \& Kuang, J. (2001). Critical factors for successful implementation of enterprise systems. Business process management journal, 7(3), 285-296.

Cooke-Davies, T. (2002). The "real" success factors on projects. International journal of project management, 20(3), 185-190.

Hendricks, K. B., \& Singhal, V. R. (1996). Quality awards and the market value of the firm: An empirical investigation. Management science, 42(3), 415-436.

Holland, C. P., \& Light, B. (1999). A critical success factors model for ERP implementation. IEEE software, 16(3), 30 .

Hong, K. K., \& Kim, Y. G. (2002). The critical success factors for ERP implementation: an organizational fit perspective. Information \& Management, 40(1), 25-40.

Kilic, H. S., Zaim, S., \& Delen, D. (2015). Selecting “The Best” ERP system for SMEs using a combination of ANP and PROMETHEE methods. Expert Systems with Applications, 42(5), 2343-2352.

Lin Moe, T., \& Pathranarakul, P. (2006). An integrated approach to natural disaster management: public project management and its critical success factors. Disaster Prevention and Management: An International Journal, 15(3), 396-413.

Marzagão, D. S. L., \& Carvalho, M. M. (2016). Critical success factors for Six Sigma projects. International Journal of Project Management, 34(8), 1505-1518.

Parast, M. M. (2011). The effect of Six Sigma projects on innovation and firm performance. International Journal of Project Management, 29(1), 45-55.

Pinto, J. K., \& Slevin, D. P. (1987). Critical factors in successful project implementation. IEEE transactions on engineering management, (1), 22-27.

Pinto, J. K., \& Prescott, J. E. (1988). Variations in critical success factors over the stages in the project life cycle. Journal of management, 14(1), 5-18.

Pinto, J. K., \& Slevin, D. P. (1989). Critical success factors in R\&D projects. Research-technology management, 32(1), 31-35.

Raymond, L., \& Bergeron, F. (2008). Project management information systems: An empirical study of their impact on project managers and project success. International Journal of Project Management, 26(2), 213-220.

Somers, T. M., \& Nelson, K. (2001, January). The impact of critical success factors across the stages of enterprise resource planning implementations. In System Sciences, 2001. Proceedings of the 34th Annual Hawaii International Conference on (pp. 10-pp). IEEE.

Sumner, M. (1999, April). Critical success factors in enterprise wide information management systems projects. In Proceedings of the 1999 ACM SIGCPR conference on Computer personnel research (pp. 297-303). ACM.

Todorović, M. L., Petrović, D. Č., Mihić, M. M., Obradović, V. L., \& Bushuyev, S. D. (2015). Project success analysis framework: A knowledge-based approach in project management. International Journal of Project Management, 33(4), 772-783.

Umble, E. J., Haft, R. R., \& Umble, M. M. (2003). Enterprise resource planning: Implementation procedures and critical success factors. European journal of operational research, 146(2), 241-257.

Westerveld, E. (2003). The Project Excellence Model@: linking success criteria and critical success factors. International Journal of project management, 21(6), 411-418.

Yalegama, S., Chileshe, N., \& Ma, T. (2016). Critical success factors for community-driven development projects: A Sri Lankan community perspective. International Journal of Project Management, 34(4), 643-659.

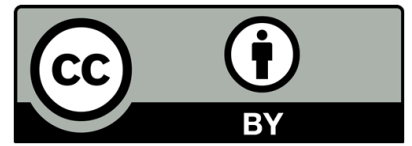

(C) 2017 by the authors; licensee Growing Science, Canada. This is an open access article distributed under the terms and conditions of the Creative Commons Attribution (CC-BY) license (http://creativecommons.org/licenses/by/4.0/). 